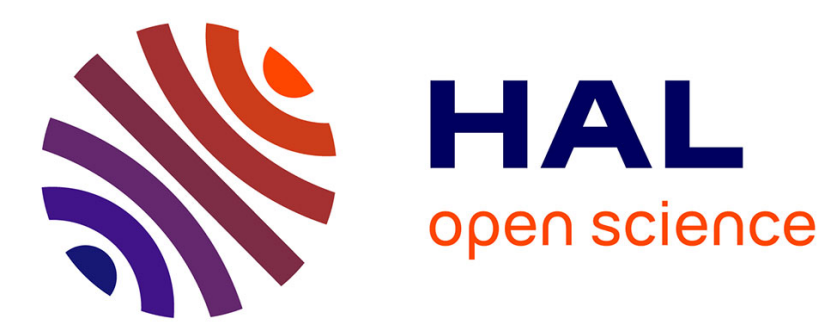

\title{
Experimental Investigation of Electro-thermal Stress Impact on SiC-BJTs Electrical Characteristics
}

Thibault Chailloux, Cyril Calvez, Pascal Bevilacqua, Dominique Planson, Dominique Tournier

\section{- To cite this version:}

Thibault Chailloux, Cyril Calvez, Pascal Bevilacqua, Dominique Planson, Dominique Tournier. Experimental Investigation of Electro-thermal Stress Impact on SiC-BJTs Electrical Characteristics. HiTEN'13, Jul 2013, Oxford, United Kingdom. hal-03326669

\section{HAL Id: hal-03326669 https://hal.science/hal-03326669}

Submitted on 26 Aug 2021

HAL is a multi-disciplinary open access archive for the deposit and dissemination of scientific research documents, whether they are published or not. The documents may come from teaching and research institutions in France or abroad, or from public or private research centers.
L'archive ouverte pluridisciplinaire HAL, est destinée au dépôt et à la diffusion de documents scientifiques de niveau recherche, publiés ou non, émanant des établissements d'enseignement et de recherche français ou étrangers, des laboratoires publics ou privés. 


\title{
Experimental Investigation of Electro-thermal Stress Impact on SiC-BJTs Electrical Characteristics
}

\author{
Thibaut Chailloux, Cyril Calvez, Pascal Bevilacqua, Dominique Planson, Dominique Tournicr \\ Corresponding author: dominique.tournier@insa-lyon.fr \\ Ampère Laboratory. \\ Bât. Léonard de Vinci, 21, avenue Jean Capelle \\ 69621, Villeurbanne cedex, France
}

\begin{abstract}
The aim of this study consists in investigating the effects of electrical and thermal stresses on SiC n-p-n bipolar junction transistors (BJTs). The stability of the electrical characteristics of BJTs is inspected under switching operation, DC operation, temperature cycling and continuous thermal stress up to $225^{\circ} \mathrm{C}$. While switching operation and temperature cycling for several hours lead to significant changes at $25^{\circ} \mathrm{C}$, the electrical characteristics were little degraded at high temperature. Besides, DC operation and continuous thermal stress did not result in significant degradation at all, both at room temperature and at high temperature.
\end{abstract}

Key words - BJT, Silicon carbide, electrical stress, thermal stress, stability.

\section{Introduction}

Thanks to technological improvements in the $\mathrm{SiC}$ sector those last years, several $\mathrm{SiC}$ components (MOSFET, JFET and BJT) have reached maturity and the fabrication of very high power converter operating at high temperature has become possible. However, the stability of these components is still an issue, especially for high temperature applications, and is strongly dependent on the packaging. Ageing and reliability tests have already been performed on different $\mathrm{SiC}$ components, such as MOSFET [4][6], JFET [1][2] and BJT [3][5][7]. Since we considered BJTs as interesting candidates, we chose to study the stability of their characteristics on last generation components and subject them to a thorough ageing.

\section{Ageing and Measurement Resources}

Ageing Resources

In order to apply a thermal stress for a long time, transistors are placed on an aluminum block $(100 \times 60 \times 35 \mathrm{~mm})$, with an Acim Jouanin heating cartridge (500W, $100 \mathrm{~mm}$ long) inside. The temperature of the components is measured thanks to a type $\mathrm{K}$ thermocouple placed on their case and is controlled with a Jumo iTron 16 PID controller. A Thermonics thermal conditioner (T-2500) has also been used in some tests for fast temperature cycling.

The electrical stress was applied between collector and emitter by laboratory power supplies, such as a
3.3kW Genesys 600-5.5 TDK-Lambda, in series with a resistive load.

\section{Measurement resources}

The measurements have been made with an Agilent Curve Tracer (B1505).

\section{Components}

The tests have been performed on $4 \mathrm{H}-\mathrm{SiC}$ NPN power bipolar junction transistors supplied by TranSiC.. During our experimentations, we used either BitSiC B'T $1206 \mathrm{AB}$ or B'T'1220AB, which have the same chip but with a larger die size for the BT1220AB. Both devices are packaged in TO258, rated at $V_{\text {ce } 0}=1200 \mathrm{~V}$ and $T_{j M A X}=250^{\circ} \mathrm{C}$. BT $1206 \mathrm{AB}$ can only withstand $\mathrm{I}_{\mathrm{c} M \Lambda x}=6 \mathrm{~A}$ at $\mathrm{T}_{\mathrm{j}}=25^{\circ} \mathrm{C}$, while $\mathrm{BT} 1220 \mathrm{AB}$ handles $20 \mathrm{~A}$. According to the manufacturer, they are supposed to have a small onresistance $(<50 \mathrm{~m} \Omega)$.

\section{Measurements and Results \\ Description of experimental setups}

In order to compare ageing speeds, different stresses were applied and so different setups were used. Meanwhile, their $I_{C E}-V_{C E}$ characteristics have been measured at short time intervals. Impacts of temperature on electrical characteristics both during tests and after (irreversible evolutions) have 
been investigated. We observed the variation of clectrical characteristics while applying:

- (S\#1) only a $10 \mathrm{kHz}$ electrical stress,

- (St/2) only a $150^{\circ} \mathrm{C}$ continuous thermal stress,

- (S\#3) only temperature cycling $\left(1^{\circ} \mathrm{C} / \mathrm{s}\right)$ between $25^{\circ} \mathrm{C}$ and $150^{\circ} \mathrm{C}$,

- (S $/ 14) 4$ temperature cycles between $25^{\circ} \mathrm{C}$ and $225^{\circ} \mathrm{C}$,

- (S//5) 4 temperature cycles between $25^{\circ} \mathrm{C}$ and $225^{\circ} \mathrm{C}$ and a $10 \mathrm{kHz}$ clectrical stress

- (SH6) 4 temperature cycles between $25^{\circ} \mathrm{C}$ and $225^{\circ} \mathrm{C}$ and a $3 \mathrm{~A} \mathrm{DC}$ stress.

\section{S\#1 First setup: $10 \mathrm{kHz}$ electrical stress}

Switching tests were performed with a $150 \Omega$ load and $500 \mathrm{~V}$ source. A home-made current driver with an output current swing capability of $1 \mathrm{~A}$ was used for driving the BJTs. For this setup, the output current was set to $400 \mathrm{~mA}$ with a switching frequency of $10 \mathrm{kHz}$ and a duty cycle of 0.5 , during 10 hours.

Low collector current rise and fall times $\left(t_{1}=150 \mathrm{~ns}\right.$, $\mathrm{t}_{\mathrm{l}}=180 \mathrm{~ns}$ ) were recorded (Fig. 1 and 2) for switching $3.3 \mathrm{~A}$ at $500 \mathrm{~V}$ and were temperatureinvariant, due to the "unipolar" nature of the $\mathrm{SiC}$ BJ'T' device design.

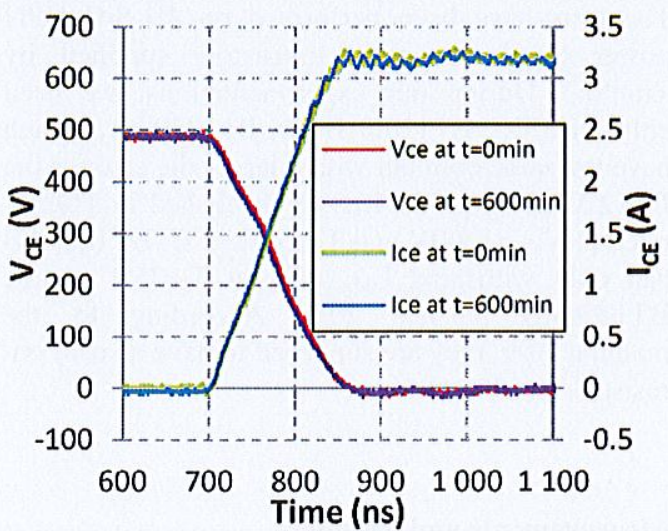

Fig. 1: Collector current rise time before and after $\mathbf{1 0}$ hour switching tests.

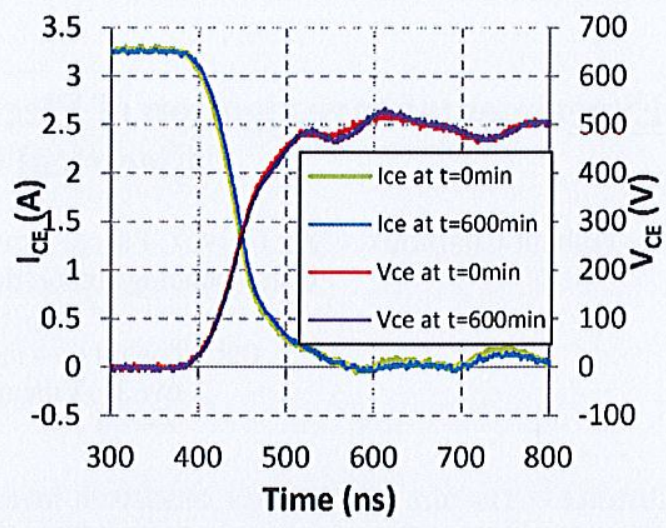

Fig. 2: Collector current fall time before and after 10 hour switching tests.

From $I_{C E}-V_{C E}$ characteristic curves at different base currents, the On-resistance can be extracted (Fig. 3).

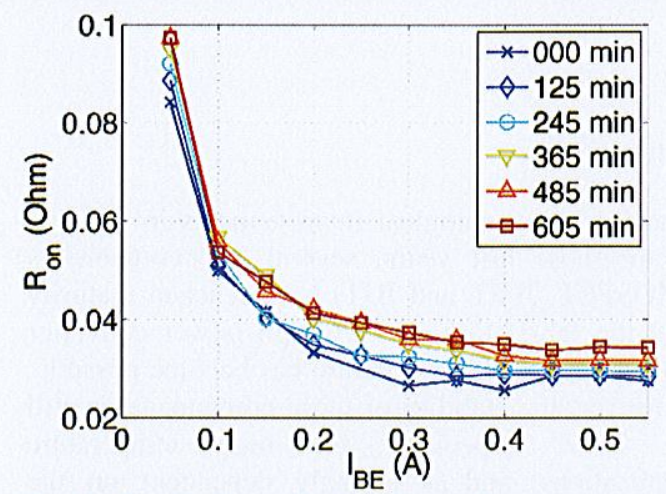

Fig. 3: Evolution of the On-resistance versus base current during the switching tests. The colour of the curves becomes warmer with increasing time.

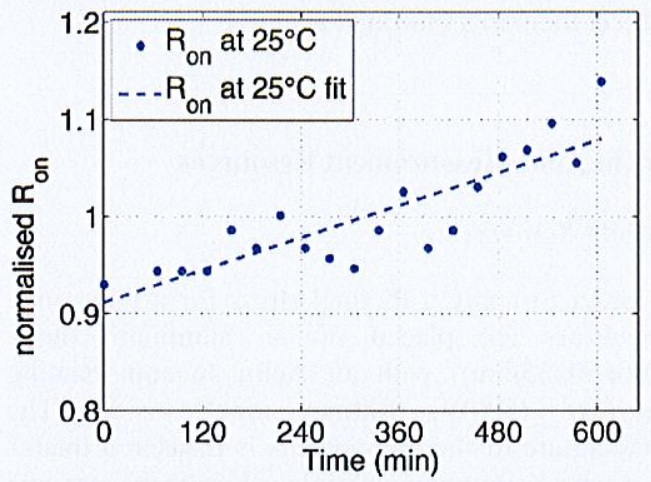

Fig. 4: Evolution of the On-resistance normalised by its mean value versus time for a $400 \mathrm{~mA}$ base current. The resistance increases by an average of $1.8 \%$ by hour. 
Figure 4 shows the variation of On-resistance at $I_{B}=400 \mathrm{~mA}$ normalised by its mean valuc.

$$
\frac{R_{o n}}{\overline{R_{o n}}}
$$

After the switching tests, the On-resistance at $I_{B}=400 \mathrm{~mA}$ increased by $18 \%$. (Fig. 4)

\section{S\#2 Second setup: $150^{\circ} \mathrm{C}$ continuous thermal stress}

A second sample has been characterized before, during and after a 10-hour long continuous thermal stress at $150^{\circ} \mathrm{C}$ without any electrical stress. The On-resistance value increases continuously during the heating process (Fig. 6). After the thermal agcing, the On-resistance at $25^{\circ} \mathrm{C}$ decreased by $12 \%$ and its value at $150^{\circ} \mathrm{C}$ decreased by $3 \%$ (Fig. 5,6 and 7), which is quite low.

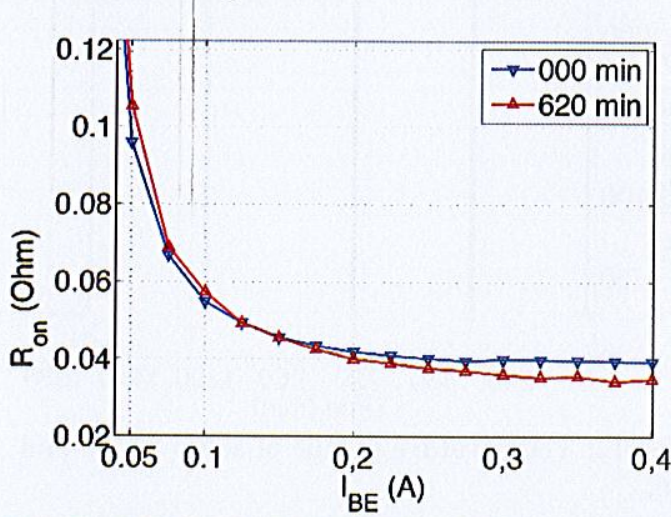

Fig. 5: Evolution of the On-resistance versus base current at $25^{\circ} \mathrm{C}$, before and after a 10 -hour long continuous thermal stress.

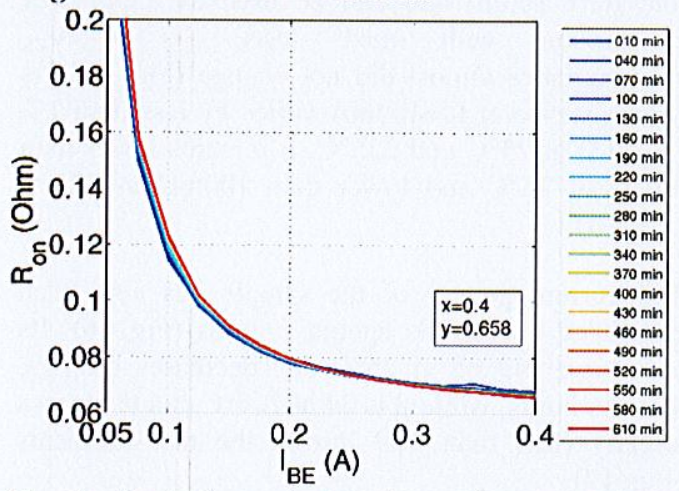

Fig. 6: Evolution of the On-resistance versus base current at $150^{\circ} \mathrm{C}$, during a 10 -hour long continuous thermal stress. The colour of the curves becomes warmer with increasing time. The variation is very slight.

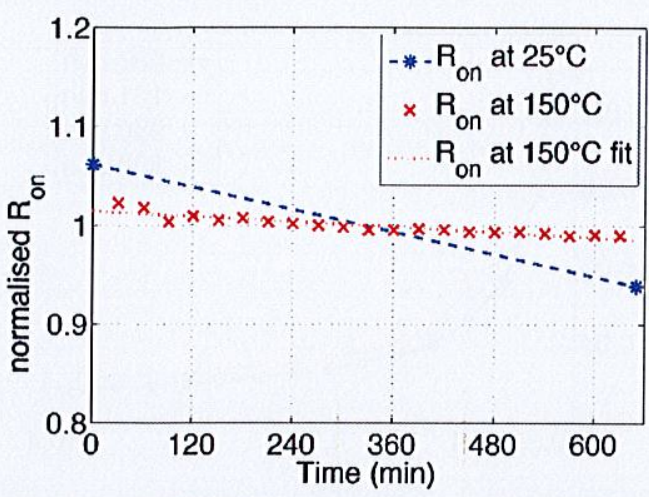

Fig. 7: Evolution of the On-resistance normalised by its mean value versus time for a $400 \mathrm{~mA}$ base current. The resistance decreases by an average of $1.2 \%$ by hour at $25^{\circ} \mathrm{C}$ and by $0.3 \%$ by hour at $150^{\circ} \mathrm{C}$.

Thus, almost no variations during the plateau at $150^{\circ} \mathrm{C}$ have been observed. The degradation at $25^{\circ} \mathrm{C}$ before and after heat stress may be due to the rapid increase and decrease in temperature $\left(60^{\circ} \mathrm{C} / \mathrm{min}\right)$. The next step of our work consists in observing the effect of temperature cycling on electrical characteristics.

\section{S\#3 Third setup: Temperature cycling}

A third sample has been stressed by temperature cycling between $25^{\circ} \mathrm{C}$ and $150^{\circ} \mathrm{C}$ at a rising and falling speed of $60^{\circ} \mathrm{C} /$ minute, in order to observe the effects of temperature change. (Fig. 8)

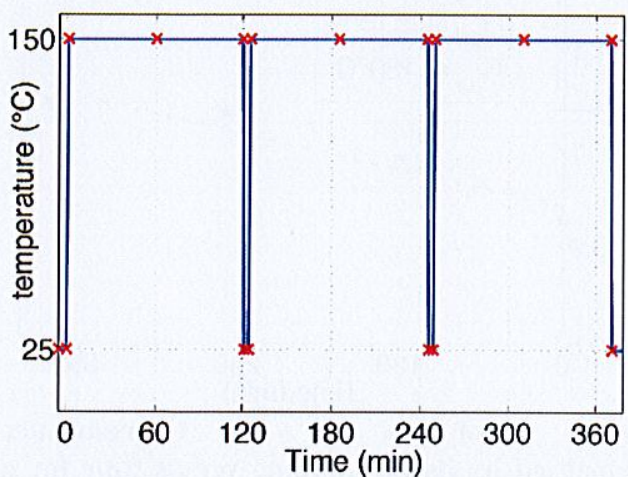

Fig. 8: Temperature profile of setup \#3.

Figures 9 and 10 show the variation of Onresistance at $25^{\circ} \mathrm{C}$ and at $150^{\circ} \mathrm{C}$. The sudden increase in the resistance value at $\mathrm{t}=120 \mathrm{~min}$ and $\mathrm{t}=240 \mathrm{~min}$ shows the effects of thermal cycling (Fig. 11). The overall increase after 6 hours of cycling is $13 \%$ and is approximately the same when measured at $150^{\circ} \mathrm{C}$ and at $25^{\circ} \mathrm{C}$. 


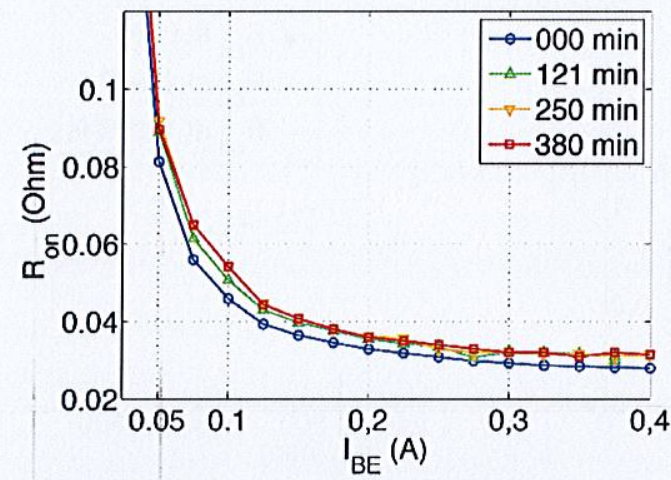

Fig. 9: Evolution of the On-resistance versus base current at $25^{\circ} \mathrm{C}$, before, during and after a thermal cycling. The colour of the curves becomes warmer with increasing time.

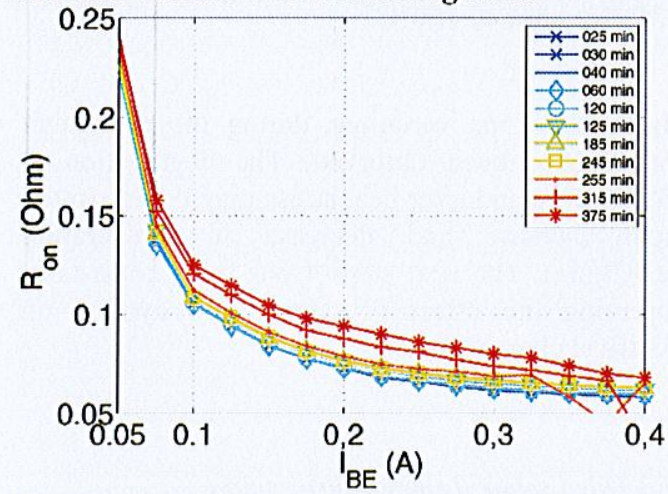

Fig. 10: Evolution of the On-resistance versus base current at $150^{\circ} \mathrm{C}$, during a thermal cycling. The colour of the curves becomes warmer with increasing time.

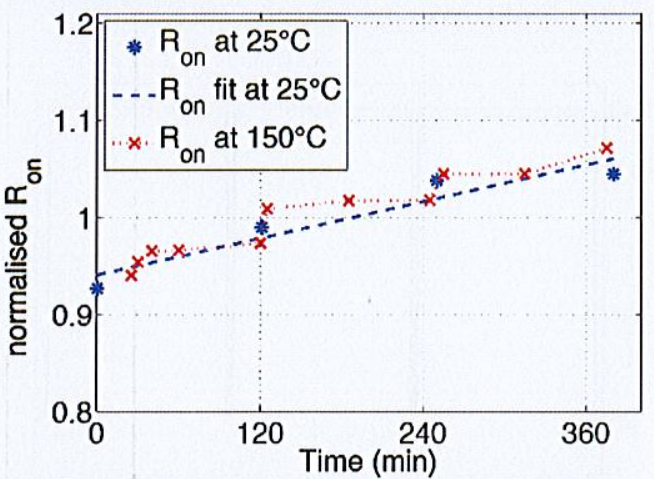

Fig. 11: Evolution of the On-resistance normalised by its mean value versus time for a $400 \mathrm{~mA}$ base current. Blue stars are normalised $R_{\text {on }}$ values at $25^{\circ} \mathrm{C}$, blue dashed line is a fitted curve at $25^{\circ} \mathrm{C}$ and red dotted line with crosses as markers is normalised $R_{\text {on }}$ values at $150^{\circ} \mathrm{C}$. The resistance increases by an average of $2.2 \%$ by hour.

From these three experiments, different kinds of stress have been observed alone. Voltage switching and temperature switching have been far more wearing than continuous stress. The next step of our work consisted in observing the combined effects of electrical and thermal stresses at a more challenging temperature.

\section{S\#4 Forth setup: $225^{\circ} \mathrm{C}$ thermal stress}

The three last samples were placed logether on the heating block, so we can assume that they were subjected to exactly the same $225^{\circ} \mathrm{C}$. heat stress for 26 hours. (Fig. 12) The temperature variation speed was lower than in previous test: $30^{\circ} \mathrm{C} /$ minute for the rising and $15^{\circ} \mathrm{C} /$ minute for the falling.

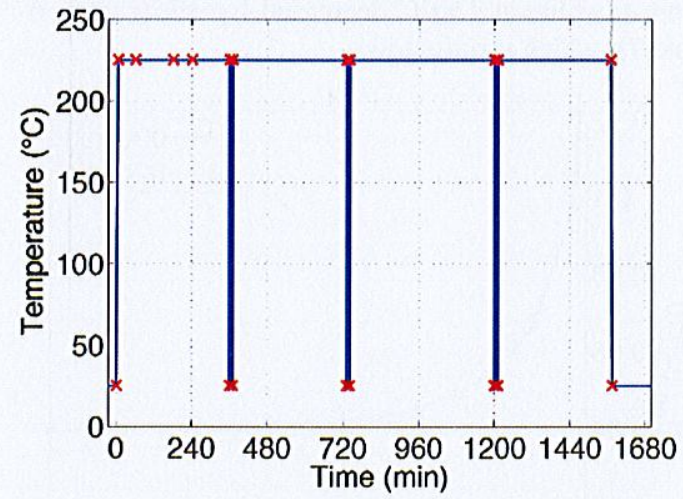

Fig. 12: Temperature profilc of setup \#4, \#5 and \#6.

One of them was subjected to no electrical stress (the forth setup) and can be used as a point of comparison with next tests. Its $\mathrm{I}_{\mathrm{CE}}-\mathrm{V}_{\mathrm{CE}}$ characteristics almost did not change (Fig. 13). Its On-resistance at $\mathrm{I}_{\mathrm{B}}=400 \mathrm{~mA}$ varies by less than $1 \%$ (Fig. 15 ) at $25^{\circ} \mathrm{C}$ and $225^{\circ} \mathrm{C}$. It remains lower than $50 \mathrm{~m} \Omega$ at $25^{\circ} \mathrm{C}$ and lower than $100 \mathrm{~m} \Omega$ at $225^{\circ} \mathrm{C}$. (Fig. 14).

The current gain $\beta$ of the sample has also been calculated during the ageing process (Fig. 16). Its value is about 6.5 at $25^{\circ} \mathrm{C}$ and decreases by $12 \%$ after 26 hours, while $\beta$ is 34 at $225^{\circ} \mathrm{C}$ and decreases slightly (less than $4 \%$ ) during the measurements (Fig. 17).

The small impact of temperature variations (at $t=360 \mathrm{~min}, t=720 \mathrm{~min}$ and $t=1200 \mathrm{~min}$ ) can certainly be explained by a compensation between the decrease noted at a constant stress (setup \#2) and increase observed during temperature changes (setup \#3). Moreover the temperature changes are smoother so the thermal cycling effects are probably lesser. In any case, the small overall Onresistance variation is very encouraging. 


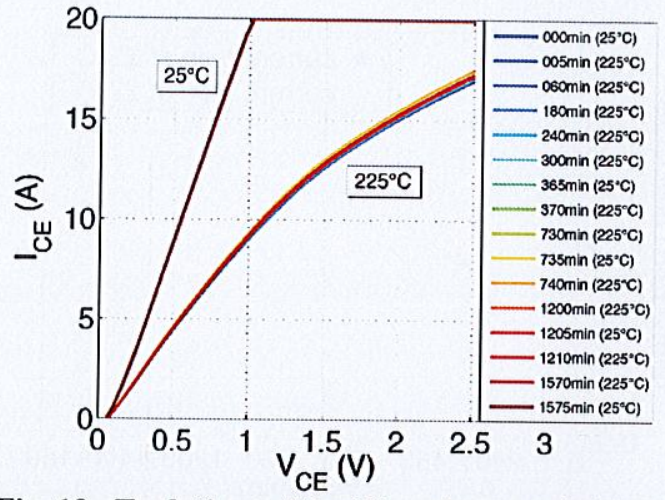

Fig. 13: Evolution of $I_{C E}-V_{C E}$ characteristics at $I_{B E}=400 \mathrm{~mA}$ with ageing. The colour of the curves becomes warmer with increasing time. The variation is very small.

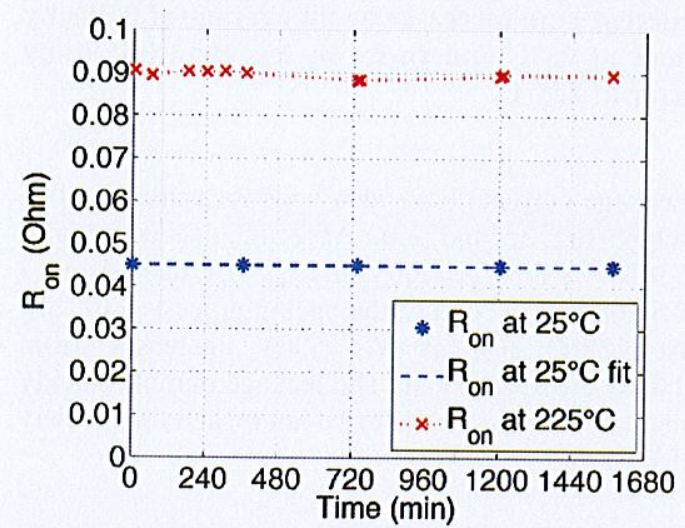

Fig. 14: Value of On-resistance versus time for a $400 \mathrm{~mA}$ base current. Blue stars are $R_{\text {on }}$ values at $25^{\circ} \mathrm{C}$, blue dashed line is a fitted curve at $25^{\circ} \mathrm{C}$ and red dotted line with crosses as markers is $R_{\text {on }}$ values at $225^{\circ} \mathrm{C}$.

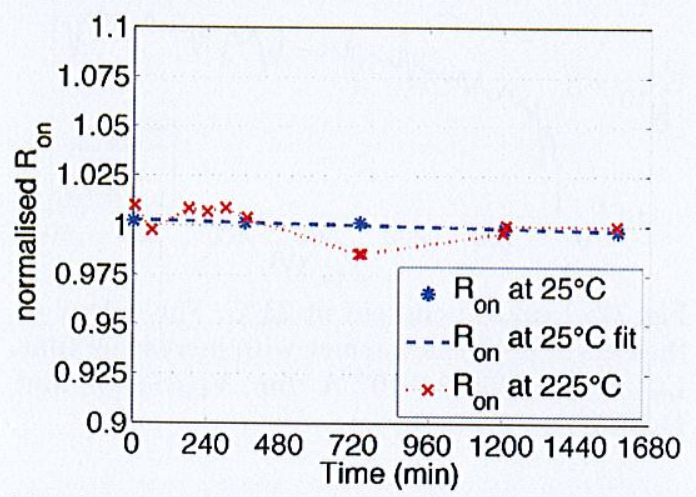

Fig. 15: Evolution of the On-resistance normalised by its mean value versus time for a $400 \mathrm{~mA}$ base current. Blue stars are normalised $R_{\text {on }}$ values at $25^{\circ} \mathrm{C}$, blue dashed line is a fitted curve at $25^{\circ} \mathrm{C}$ and red dotted line with crosses as markers is normalised $R_{\text {on }}$ values at $225^{\circ} \mathrm{C}$. The resistance decreases by an average of $0.04 \%$ by hour.

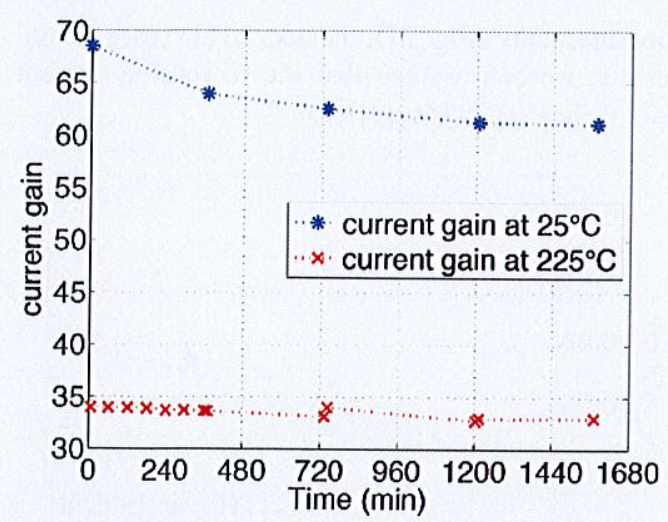

Fig. 16: Current gain $(\beta)$ versus time for $I_{B}=200 \mathrm{~mA} \quad V_{C E}=2.5 \mathrm{~V}$. Blue dotted line with stars as is $\beta$ values at $25^{\circ} \mathrm{C}$, red dotted line with crosses as markers is $\beta$ values at $225^{\circ} \mathrm{C}$.

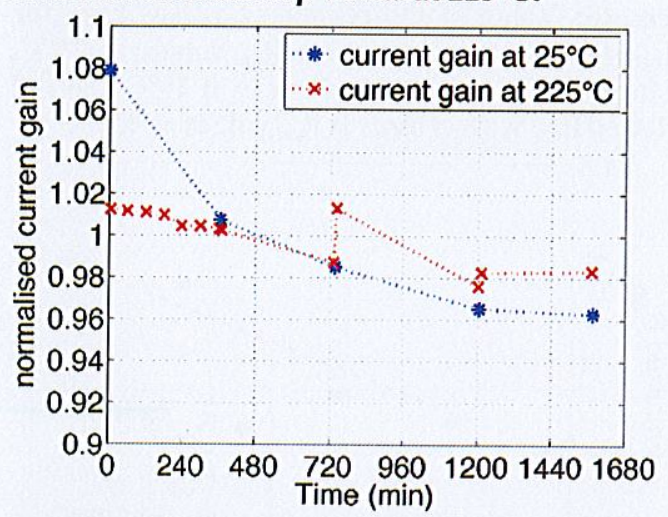

Fig. 17: Evolution of current gain $(\beta)$ normalised by its mean value versus time. Blue dotted line with stars as markers is $\beta$ values at $25^{\circ} \mathrm{C}$, red dotted line with crosses as markers is $\beta$ values at $225^{\circ} \mathrm{C}$. The current gain decreases by an average of $0.46 \%$ by hour at $25^{\circ} \mathrm{C}$ and by $0.15 \%$ by hour at $225^{\circ} \mathrm{C}$.

S\#5 Fifth setup: $225^{\circ} \mathrm{C}$ thermal stress and $10 \mathrm{kHz}$ electrical stress

The fifth device was subjected to an additional $10 \mathrm{kH}$ \% clectrical stress, with the same $500 \mathrm{~V}$ source and $150 \Omega$ load as in previous test.

Its initial On-resistance was $40 \mathrm{~m} \Omega$ at $25^{\circ} \mathrm{C}$ (Fig. 18) and increased by $48 \%$ after 26 hours of ageing (Fig. 19). Thus the resistance varies on average by $1.8 \%$ per hour. This variation fits well with the $18 \%$ variation in 10 hours observed in the first setup.

The On-resistance at $225^{\circ} \mathrm{C}$ is about $105 \mathrm{~m} \Omega$ (Fig. 18) and almost did not change (Fig. 19).

The current gain $\beta$ is about 60 at $25^{\circ} \mathrm{C}$ and increased slightly (6\% after 26 hours) while $\beta$ is 30 at $225^{\circ} \mathrm{C}$. and its variation range is $5 \%$ during the 
measurements (Fig. 21). Thanks to the forth setup results, we can assume that the increasing current gain is duc to clectrical stress.

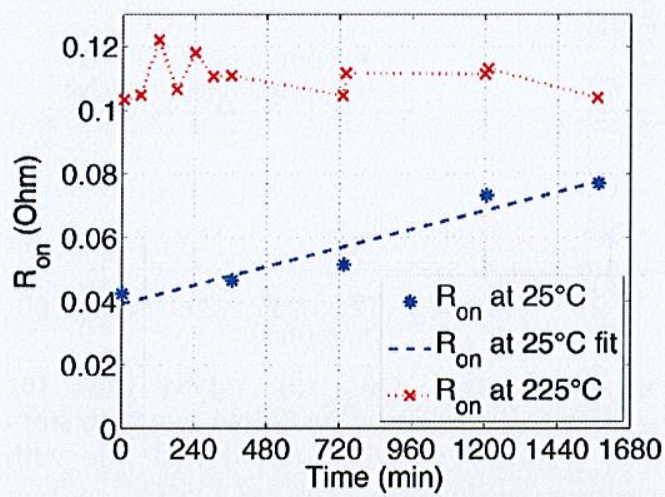

Fig. 18: Value of On-resistance versus time for $I_{B E}=400 \mathrm{~mA}$. Blue stars are $R_{o n}$ values at $25^{\circ} \mathrm{C}$, blue dashed line is a fitted curve at $25^{\circ} \mathrm{C}$ and red dotted line with crosses is $R_{\text {on }}$ values at $225^{\circ} \mathrm{C}$.

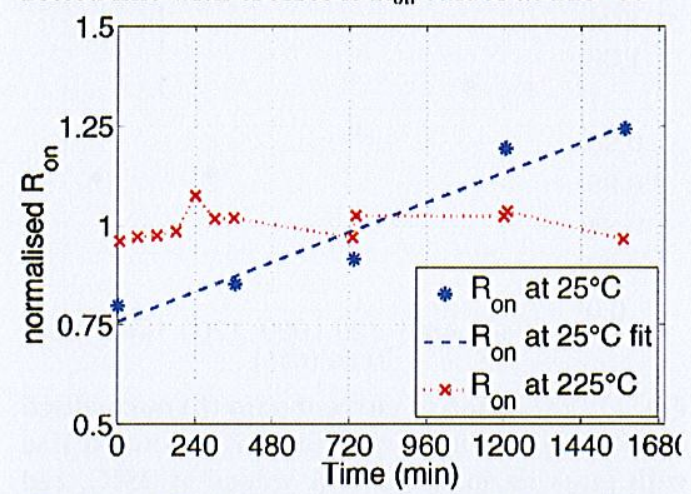

Fig. 19: Evolution of the On-resistance normalised by its mean value versus time for $I_{B E}=400 \mathrm{~mA}$. Blue stars are normalised $R_{o n}$ values at $25^{\circ} \mathrm{C}$, blue dashed line is a fitted curve at $25^{\circ} \mathrm{C}$ and red dotted line with crosses is normalised $R_{\text {on }}$ values at $225^{\circ} \mathrm{C}$. The resistance increases by an average of $1.8 \%$ by hour at $25^{\circ} \mathrm{C}$ and varies by less than $0.07 \%$ by hour at $225^{\circ} \mathrm{C}$.

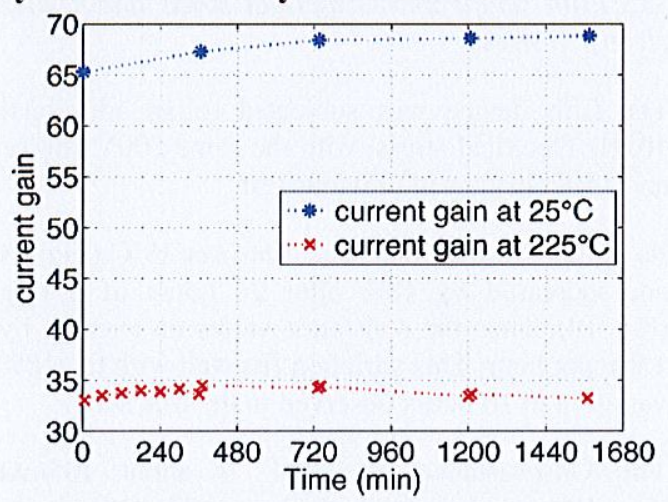

Fig. 20: Current gain ( $\beta$ ) versus time for $I_{B}=200 \mathrm{~mA} V_{C E}=2.5 \mathrm{~V}$. Blue dotted line with stars is $\beta$ values at $25^{\circ} \mathrm{C}$, red dotted line with crosses is $\beta$ values at $225^{\circ} \mathrm{C}$.

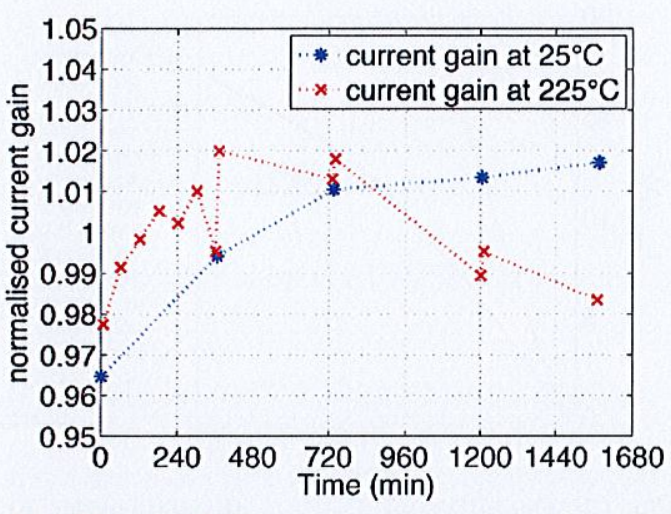

Fig. 21: Evolution of current gain $(\beta)$ normalised by its mean value versus time. Blue dotted line with stars is $\beta$ values at $25^{\circ} \mathrm{C}$, red dotted line with crosses is $\beta$ values at $225^{\circ} \mathrm{C}$. The current gain increases by an average of $0.2 \%$ by hour at $25^{\circ} \mathrm{C}$ and varies by less than $0.15 \%$ by hour at $225^{\circ} \mathrm{C}$.

Leakage currents have also been measured for this setup (Fig. 22 and 23). At $25^{\circ} \mathrm{C}, \mathrm{I}_{\mathrm{CE}}$ is initially $3.9 \cdot 10^{-10} \mathrm{~A}$ for $\mathrm{V}_{\mathrm{CE}}=500 \mathrm{~V}$ and $\mathrm{I}_{\mathrm{BE}}=0 \mathrm{~A}$, and becomes $2.5 \cdot 10^{-9} \mathrm{~A}$ at the end of the ageing process (Fig. 22). At $225^{\circ} \mathrm{C}, I_{\mathrm{CE}}$ at $V_{\mathrm{CE}}=500 \mathrm{~V}$ increases from $1.8 \cdot 10^{-8} \mathrm{~A}$ to $4.7 \cdot 10^{-6} \mathrm{~A}$. The leakage current quickly increases within the first two hours, and then slowly decreases.

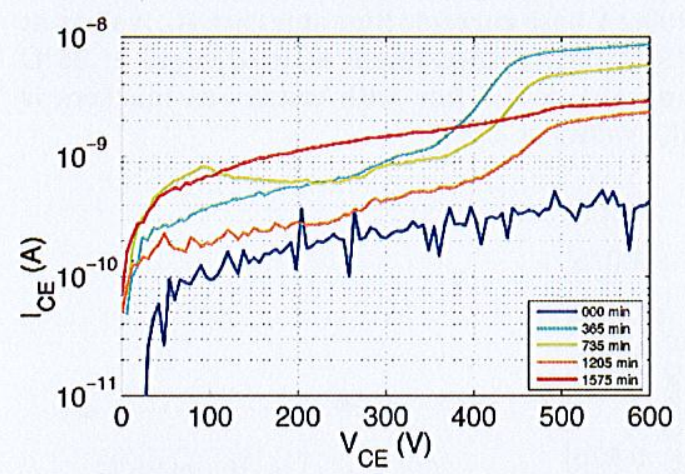

Fig. 22: Leakage current at $25^{\circ} \mathrm{C}$. The colour of the curves becomes warmer with increasing time. $I_{C E}$ is initially $3.9 \cdot 10^{-10} \mathrm{~A}$ for $V_{C E}=500 \mathrm{~V}$ and $\mathrm{I}_{\mathrm{BF}}=\mathbf{0 A}$ 


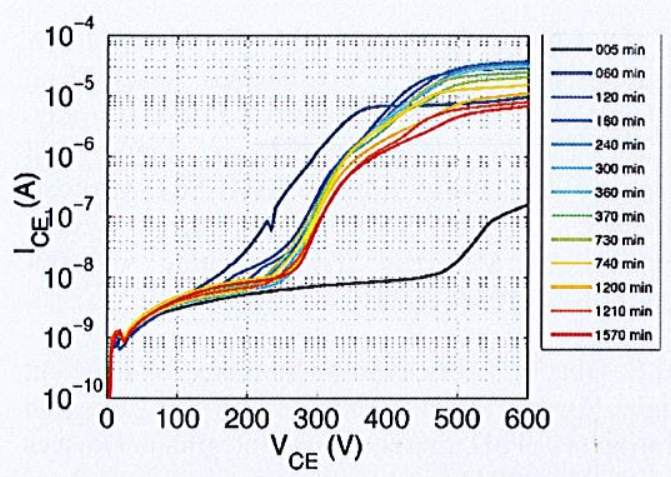

Fig. 23: Leakage current at $225^{\circ} \mathrm{C}$. The colour of the curves becomes warmer with increasing time.

S\#6 Sixth setup: $225^{\circ} \mathrm{C}$ thermal stress and $D C$ stress

Besides the thermal stress, the sixth device was subjected to a $3 A D C$. electrical stress.

Its initial On-resistance was $42 \mathrm{~m} \Omega$ at $25^{\circ} \mathrm{C}$ and $95 \mathrm{~m} \Omega$ at $225^{\circ} \mathrm{C}$ (Fig. 24) and increased by less than $1 \%$ after 26 hours (Fig. 25).

The current gain with DC stress almost follows the same variation as in the previous setup. It increases by $12 \%$ at $25^{\circ} \mathrm{C}$ and varies by less than $6 \%$ at $225^{\circ} \mathrm{C}$ (Fig. 27). At $225^{\circ} \mathrm{C}$, it seems to that electrical stress and thermal ageing compensate each other.

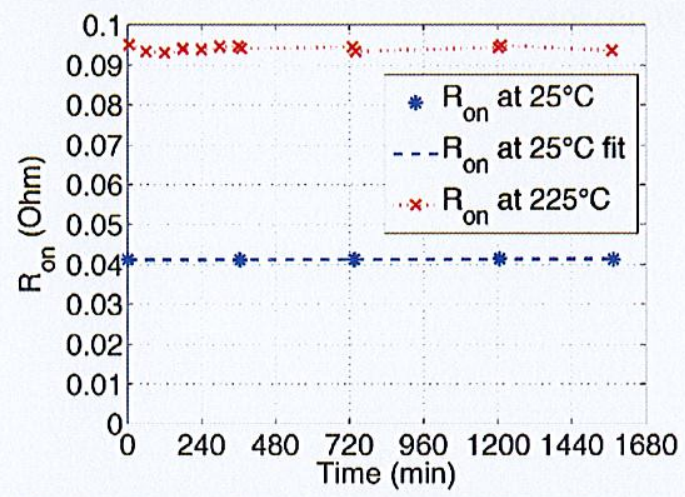

Fig. 24: Value of On-resistance versus time for a $400 \mathrm{~mA}$ base current. Blue stars are $R_{\text {on }}$ values at $25^{\circ} \mathrm{C}$, blue dashed line is a fitted curve at $25^{\circ} \mathrm{C}$ and red dotted line with crosses as markers is $R_{\text {on }}$ values at $225^{\circ} \mathrm{C}$.

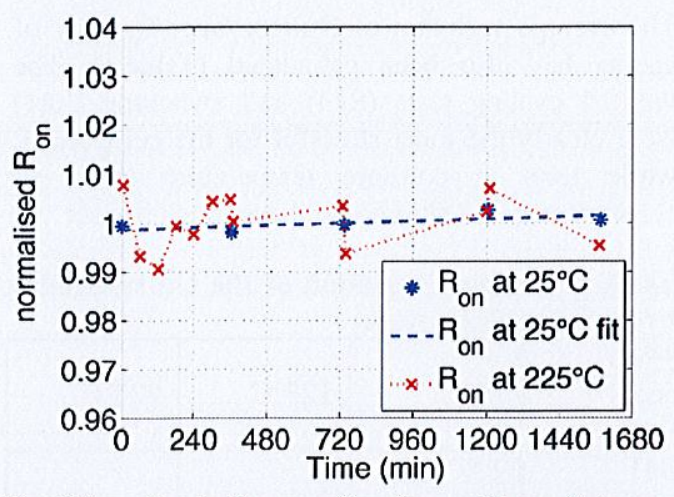

Fig. 25: Evolution of the On-resistance normalised by its mean value versus time for a $400 \mathrm{~mA}$ base current. Blue stars are normalised $R_{\text {on }}$ values at $25^{\circ} \mathrm{C}$, blue dashed line is a fitted curve at $25^{\circ} \mathrm{C}$ and red dotted line with crosses as markers is normalised $R_{\text {on }}$ values at $225^{\circ} \mathrm{C}$ ). The resistance varies by less than $0.04 \%$ by hour at $25^{\circ} \mathrm{C}$ and by $0.07 \%$ by hour at $225^{\circ} \mathrm{C}$.

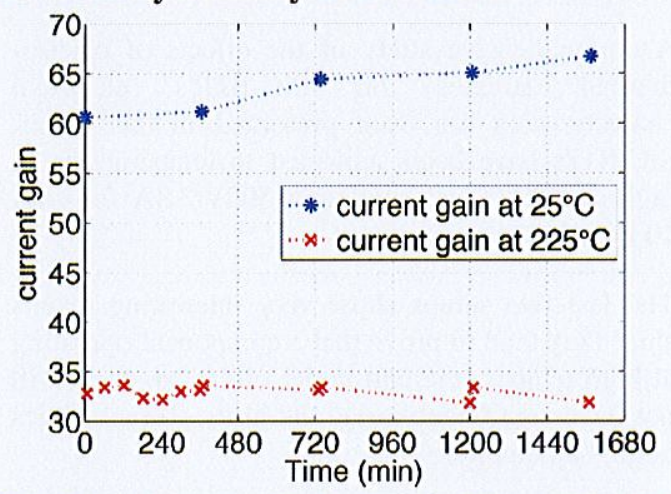

Fig. 26: Current gain ( $\beta$ ) versus time for $I_{B}=200 \mathrm{~mA} V_{C E}=2.5 \mathrm{~V}$. Blue dotted line with stars as markers is $\beta$ values at $25^{\circ} \mathrm{C}$, red dotted line with crosses as markers is $\beta$ values at $225^{\circ} \mathrm{C}$.

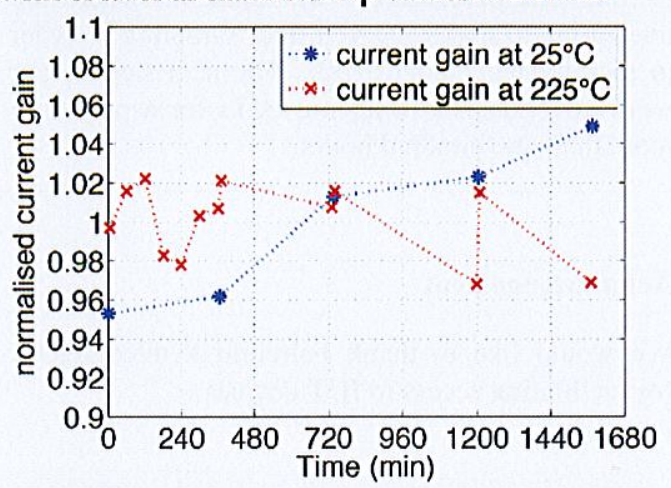

Fig. 27: Evolution of current gain $(\beta)$ normalised by its mean value versus time. Blue dotted line with stars as markers is $\beta$ values at $25^{\circ} \mathrm{C}$, red dotted line with crosses as markers is $\beta$ values at $225^{\circ} \mathrm{C}$. The current gain increases by an average of $0.36 \%$ by hour at $25^{\circ} \mathrm{C}$ and varies by less than $0.15 \%$ by hour at $225^{\circ} \mathrm{C}$. 
The average variation of On-resistance by hour of ageing has also been calculated (Table 1). The thermal cycling tests (S\#3) and switching (S\#1) were clearly the most stressful for the component, while tests at constant temperature $(\mathrm{S} \# 2)$ or constant current (S\#6) do not have much impact.

Table 1: Average variation of the On-resistance by hour for each setup.

\begin{tabular}{|l|l|l|l|}
\hline $\begin{array}{l}\frac{\Delta R_{\text {on }}}{\overline{R_{\text {on }}}} / \Delta t \\
\text { (in \%/h) }\end{array}$ & $25^{\circ} \mathrm{C}$ & $125^{\circ} \mathrm{C}$ & $225^{\circ} \mathrm{C}$ \\
\hline \hline S\#1 & 1.8 & & \\
S//2 & -1.2 & -0.3 & \\
SH3 & 2.2 & 2.2 & \\
S 14 & -0.04 & & -0.04 \\
SH5 & 1.8 & & $<0.07$ \\
S\#6 & $<0.04$ & & $<0.04$ \\
\hline
\end{tabular}

\section{Conclusion}

A comprehensive study of the effects of electrothermal stresses on SiC-BJT's electrical characteristics has been presented in this paper. SiC-BJTs have been subjected to temperatures as high as $225^{\circ} \mathrm{C}$ and swilching $500 \mathrm{~V} / 3.3 \mathrm{~A}$ for over 10 hours.

The last two setups show very interesting results since they tend to prove that a component operating at high temperature and under electrical stress will not have significant variations in its characteristics at high temperature.

Besides, we noted that the changes were relatively significant during the carly hours of aging, so we made more measurements at the beginning of each of our tests. However, we think it would be interesting to make an even finer sampling in order to identify more than trends. The next step of our work also consists in agcing BJTs for a period of more than one hundred hours.

\section{Acknowledgement}

We would like to thank Fairchild Semiconductor for facilitating access to BJT devices.

\section{References}

[1] L. Cheng, P. Martin, M. S. Mazzola, V. Bondarenko, H. Causey, J. R. B. Casady, J. B. Casady, High-Temperature reliability of $4 \mathrm{H}-\mathrm{SiC}$ Vertical-Channel Junction Field Effect Transistors (VJFETs) for Power Conditioning System Applications, HITEC, 2006.
[2] L. Cheng, P. Martin, M. S. Mazzola, D. Sheridan, R. L. Kelly, V. Bondarenko, S. Morrison, R. Gray, G. Y. Tian, J. D. Scofield, J. R. B. Casady, J. B. Casady, High-'lemperature Static and Dynamic Reliability Study of $4 \mathrm{H}-\mathrm{SiC}$ VerticalChannel JFETs for High-Power System Applications, Materials Science Forum, vol.600603 , p. 1051-1054, 2009.

[3] R. Ghandi. Fabrication Technology for Efficient High Power Silicon Carbide Bipolar Junction Transistors. PhD thesis, KTH, Integrated Devices and Circuits, 2011.

[4] R. Green, A. Lelis, D. Habersat, Application of reliability test standards to $\mathrm{SiC}$ power MOSFETs. In Reliability Physics Symposium (IRPS), 2011 IEEE International, p. EX.2.1-EX.2.9, 2011.

[5] S. L. Kaplan, A. Ogunniyi, Reliability Testing of $4 \mathrm{H}-\mathrm{SiC}$ Bipolar Junction Transistors in Continuous Switching Applications, Materials Science Forum, vol. 600-603, p. 1167-1170, 2009.

|6| M. Le-Huu, H. Schmitt, S. Noll, M. Grieb, F. F. Schrey, A. J. Bauer, L. Frey, H. Ryssel, Investigation of the reliability of $4 \mathrm{H}-\mathrm{SiC}$ MOS devices for high temperature applications, Microelectronics Reliability 51, p. 1346-1350, 2001.

[7] S. Sundaresan, A. Soe, S. Jeliazkov, R. Singh, Characterization of the Stability of Current Gain and Avalanche-Mode Operation of 4H-SiC BJTs, IEEE Trans on Flectron Devices, p. 2795-2802, Vol. $59,10,2012$. 